\title{
Towards chiral 1,2-propanediols via desymmetrization
}

\section{Edmilson Clarindo de Siqueira and Bogdan Doboszewski}

\author{
Departamento de Química, Universidade Federal Rural de Pernambuco, 52171-900 Recife, PE, Brasil
}

\section{*bdoboszewski@hotmail.com}

Keywords: chiral auxiliary, desymmetrization, propanediol

\section{INTRODUCTION}

General tendency in the pharmaceutical industry is to use either a chiral substrates or to perform chiral separations to obtain only one specific isomer as an active principle in order to decrease a metabolic load in patient's organism. Tenofovir $\mathbf{1}$ is an active<smiles>C[C@H](Cn1cnc2c(N)ncnc21)OCP(=O)(O)O</smiles><smiles>[R]C[C@H](C)O</smiles>

principle of the Viraed $\mathrm{B}$ and is liberated from its prodrug form. Viraed $\AA$ is approved for treatment of HIV and HBV infections as an inhibitor of reversed transcriptase. One of the components of Tenofovir is $(R)$ - 1,2-propanediol 2. Reported here are initial stages of obtention of (R) 2 and its enantiomer (S) 2 via desymmetrization of easily available glycerol and racemic 1,2-propanediol.

\section{RESULTS AND DISCUSSION}

Our initial attempts to use biphthalate 3 and derivatives of aminoacids as chiral auxiliaries ( $L$ lysine, L-serine) were negative. Inconsistent results<smiles>C[C@H](COC(=O)c1ccccc1C(=O)O)OC(=O)c1ccccc1C(=O)O</smiles>

3<smiles>C[C@H](N)c1ccccc1</smiles>

(R) 4<smiles>C[C@H](N)c1ccccc1</smiles>

(S) 5 were obtained during application of brucine: even though a crystalline material was obtained which was submitted for $\mathrm{x}$-ray analysis, the process of crystallization was difficult to reproduce, and this approach was abandoned, even though application of strychnine was published for the same purpose. ${ }^{1}$ Since both (R) and (S)-1-phenylethylamines 4 and $\mathbf{5}$, respectively, are available commercially, we used them next. Disappointingly, a salt formed between 3 and $\mathbf{4}$ is not a crystalline material. However, a phthalate 6 derived from racemic 1,2- isopropylideneglycerol and amine $(R) 4^{2,3}$ permitted to obtain (S) 1,2-isopropylidene glycerol 7 via a series of crystallizations, followed by removal of<smiles>CC1(C)OC[C@@H](COC(=O)c2ccccc2C(=O)[O-])O1</smiles>

6

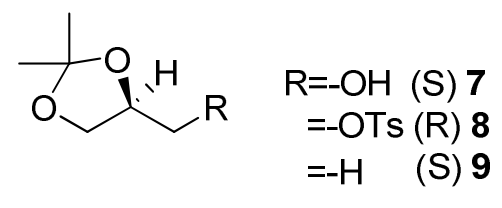

chiral auxiliary and phthalate moiety. Tosylate (R) 8 derived from (S) 7 is a precursor of (S) 9, which in turn permits obtention of the target (S) 2 (via $\mathrm{NaBH}_{4}$ reduction and hydrolysis).

Following the same procedure, racemic phthalate 6 on treatment with the amine (S)-5 furnished a salt which is a precursor of $(R) \mathbf{1 0}$ and eventually of the (R) 2.

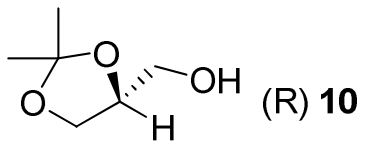

Work is underway to find a method to obtain both enantiomeric diols 2 directly from racemic 3 in order to avoid tosylation and reduction.

\section{CONCLUSION}

Desymmetrization of phthalate 6 using auxiliary amines 4 and $\mathbf{5}$, followed by simple reduction is a way to access both diols (R) and (S) 2.

\section{ACKNOWLEDGEMENTS}

Instituto Nacional de Ciência e Tecnologia para Inovação Farmecêutica is acknowledged for financial support.

\section{REFERENCES}

${ }^{1}$ Norula, J.L. Chemical Era, 1975, 11, 21

2 Pallavicini, M.; Valoti, E.; Villa, L.; Piccolo, O. Tetrahedron: Asymmetry, 1994, 5, 5.

2 Sterochemistry of Organic Compounds. Eliel, E.L.; Wilen, S.H.; Mander, L.N. John Wiley and Sons, New York, 1994.

$14^{\text {th }}$ Brazilian Meeting on Organic Synthesis $-14^{\text {th }}$ BMOS - September 01-05, 2011-Brasilia, Brazil 